\title{
Eurasia and the transnational terrorist threats to Atlantic security
}

\author{
Phil Williams
}

The terrorist attacks of September 11 on the World Trade Center and the Pentagon were not only the most audacious and successful terrorist attacks the world has yet seen, but also marked the maturation of what had been described as the 'new terrorism'. It was a maturation in several senses. In the first place it revealed that trends identified by astute specialists such as Walter Laqueur, Bruce Hoffman and Ian Lesser were, in fact, well advanced. ${ }^{1}$ These analysts had suggested that terrorists were increasingly pursuing grander and less specific political objectives than in the past, were moving towards greater ruthlessness and lethality, and were less likely to claim credit for their actions. ${ }^{2}$ These characteristics were evident in the attacks of September 11. Traditionally terrorism was primarily about theatre - about lots of people watching rather than lots of people killed. ${ }^{3}$ The terrorism of September 11 was about millions of people watching several thousand people being killed. Similarly, terrorism traditionally had been about the attainment of a well-defined political objective. The attacks on the World Trade Center and the Pentagon, in contrast, appeared to be an attack on American cultural and political hegemony, and an effort to galvanise a new pan-Islamic anti-western identity rather than a serious effort to make the United States withdraw its forces from Saudi Arabia or reduce its support for Israel. Moreover, Bin Laden and al-Qaeda denied responsibility in the hope that anonymity would enable them to avoid retribution. All that was lacking from the worst-case scenarios discussed by the terrorism analysts was the presence of weapons of mass destruction. Even without these, however, the attacks exacted a far higher death toll than any previous terrorist action.

If the attacks marked the maturation of the new terrorism they also compelled a rapid - if incomplete - maturation in the United States conception of security. Since the end of the Cold War, and the disappearance of the Soviet threat, the United States had enjoyed what appeared to be immunity 
to the business cycle and an absence of serious threats to its national security. Consequently, serious political debate over national security had been stultified. National attention had been fixated on scandals ranging from presidential indiscretions and pardons to the O. J. Simpson trial and the disappearance of a Washington intern. There had been voices in the national security community, including on the National Security Council itself, warning about transnational threats such as terrorism and organised crime. ${ }^{4}$ Yet, the military focus had remained on threats from nation-states, whether an emerging China, a resurgent Russia, or rogue states suspected of acquiring weapons of mass destruction.

In launching an audacious, well-coordinated and conceptually sophisticated attack on the United States homeland, the al-Qaeda terrorist cells responsible for the hijackings transformed a narrow debate among specialists about threats to United States security into a national preoccupation. They also succeeded in galvanising the United States into mobilising national efforts and resources in ways reminiscent of the Cold War. The Bush administration, which in its first eight months in office had been unilateralist in its approach to international issues, embraced a multilateral approach to security that also harkened back to the Cold War. With NATO invoking Article 5 for the first time in its history, the European allies provided enormous diplomatic and law enforcement support to the United States - especially in the immediate aftermath of September 11. Subsequently, the United States military response in Afghanistan created some unease in western Europe, which was exacerbated by the 'axis of evil' reference in the president's 2002 State of the Union address. The European allies also became very concerned about possible United States plans to attack Iraq in a bid to oust Saddam Hussein. If the potential for Atlantic divisions remained very considerable, however, the common interests of the United States and its European allies in combating the challenge from radical Islamic terrorism are difficult to overestimate.

This is perhaps best illustrated by the series of arrests of terrorists and disruption of cells that took place in Germany in December 2000 and elsewhere in Europe throughout 2001, both before and after September 11. Close scrutiny of these events suggests that what well-informed observers described as a series of terrorist spectaculars was very narrowly averted. ${ }^{5}$ The European cells exhibited the same lethality of intent, if not of execution, as the September 11 hijackers. The story is intriguing, with many details still obscure. In December 2000, German authorities in Frankfurt broke up a terrorist cell planning an attack in Strasbourg. Initial reports suggested that the target was a square in Strasbourg, while subsequent disclosures indicated that the target was Strasbourg cathedral. One report contended that a British cell had targeted the European Parliament and that poison gas, probably sarin, might have been the weapon of choice. ${ }^{6}$

The arrests also revealed an extensive network of terrorist cells in 
Germany, Italy, Britain, Spain, Belgium and France. The cell structure operated under two large umbrella movements, the Egyptian movement, Anathema and Exile, and an Algerian counterpart, the Salafist Group for Preaching and Combat. ${ }^{7}$ In effect, these loose multinational structures coalesced through three key individuals linked to al-Qaeda: Abu Doha (whom Italian police believe to be Rachid Kefflous), an Algerian who moved to London in 1999, was involved in the plot to bomb Los Angeles airport on the eve of the millennium, and was arrested in Britain in February 2001; Mohamed Bensakhria, leader of the Frankfurt cell; and Tarek Maaroufi, a Tunisian with Belgian citizenship, who is wanted in Italy. The Milan cell was led by a Tunisian, Essid Sami Ben Khemais, who had completed two years of training in al-Qaeda camps before moving to Milan in March 1998. Khemais helped to organise the sending of recruits to Afghanistan and was clearly linked to cells elsewhere in Europe. According to Italian authorities, the recruits met in Geneva, and used false Italian documents to fly to Pakistan, from where they were taken into Afghanistan. The Italians also inferred from the evidence that Khemais financed these activities by 'means of drugtrafficking, counterfeiting money and documents, recycling dirty money'. ${ }^{8}$ The Milan cell also circumvented immigration and employment laws by creating a bogus cooperative to bring non-EU nationals into Italy, which enabled them to qualify for work permits. ${ }^{9}$ In addition, this cell provided logistic support for its counterpart in Frankfurt as the latter planned the Strasbourg attack: stolen and false credit cards from Italy were used by members of the Frankfurt group to buy explosive materials.

When the Frankfurt cell under Bensakhria was disrupted, German authorities found a cache of automatic pistols, rifles with telescopic sights, handguns with silencers, directions for bomb building, and nails and pressure cookers. ${ }^{10}$ Communication intercepts with the Milan cell also suggested that some kind of poison gas was being prepared. ${ }^{11}$ The action by German authorities provided information that led to Operation Odin in Britain and the arrest of ten suspected terrorists in February 2001. ${ }^{12}$ Although most of them were freed, Abu Doha - one of the three key members of the al-Qaeda network in Europe - and Mustapha Labsi, who was alleged to be a coconspirator in the Los Angeles bomb plot, remained under arrest. ${ }^{13}$ Members of the Milan cell were subsequently arrested in April 2001. ${ }^{14}$ Bensakhria, who had avoided arrest in Frankfurt in December 2000, was arrested in June 2001 in Spain. ${ }^{15}$ Further arrests occurred in Spain after September 11. In September, a cell that had provided logistic support was broken up, while in November another round of arrests was made. ${ }^{16}$

Although European law enforcement and intelligence agencies had considerable success in disrupting some of the al-Qaeda-related cells in several countries, the extensiveness of the structure and the links among the groups were surprising. Through a mixture of good luck, effective law enforcement and extensive intelligence cooperation among EU members, a 
number of potentially devastating terrorist acts were foiled. The arrests, however, revealed very clearly that Europe is as much of a target for radical Islamic terrorism as is the United States. Yet, this is only one part of a larger picture in which transnational threats to European and Atlantic security continue to loom very large. Accordingly, the next section of this chapter provides a conceptual analysis and assessment of these threats. The final section then considers the nature of the responses that are required as both the United States and European governments adapt to what is a very different kind of security challenge from that for which they prepared during the Cold War.

\section{The new security paradigm}

In the long term, traditional geopolitical competition could re-emerge in Europe. The more immediate threats, however, are transnational rather than national; the geographical sources of these threats are found along Europe's periphery and beyond. Indeed, there is a new threat paradigm that needs to be understood more widely if it is to be combated with maximum effectiveness. There are nine major characteristics of this paradigm that need to be taken into account. ${ }^{17}$

First, security threats are no longer stark, dramatic, and confined largely to direct external military aggression or threats of military attack; instead they are often insidious and indirect, with both external and internal dimensions. They include overt threats such as terrorism, in which the intent is to inflict significant harm, and more subtle threats such as organised crime, which uses corruption and co-option rather than confrontation. Indeed, organised crime is the HIV of the modern state, breaking down the defences of the body politic, eroding the rule of law, and undermining the integrity of institutions of social control. Although public institutions and the rule of law in the United States and most EU member-states are sufficiently robust to withstand such an assault, the ways in which corruption and organised crime can entrench themselves should not be underestimated. Organised crime from the former Soviet Union has made considerable inroads into western countries, often allying, at least temporarily, with local organisations to expand criminal markets and activities. Moreover, criminal organisations operating in Europe and the United States are more diverse (Russian, Ukrainian, Georgian, Albanian, Nigerian, Chinese, Colombian, Italian, Kurdish and Turkish) than ever before, have a wide portfolio of criminal activities from which they derive considerable profit, and deploy a sophisticated repertoire of risk-management techniques that help to protect them from law enforcement.

The second characteristic of the transnational threat paradigm is its enduring nature: transnational threats are neither simply the flavour of the moment nor 'boutique security issues' that pale in significance compared 
with traditional military threats. On the contrary, they pose continuing and serious challenges to national and international security and stability. Transnational threats have developed as a result of long-term secular trends that are likely to intensify rather than abate in the early decades of the twenty-first century. Even if al-Qaeda is defeated any time soon - which seems unlikely - terrorism will continue to be a major threat during the twenty-first century. Religious fundamentalism, political fanaticism and economic inequities and asymmetries will continue to feed a desire for revenge that is expressed in violent attacks against the citizens of countries that are viewed as the 'enemy' or the 'infidel'. If terrorist networks seek to get even with their enemies, then transnational criminal networks are motivated by the desire to get rich. And the targets are many of the advanced postindustrial countries that are also the major targets of terrorism. Not only do these countries wield political, economic and military power in ways that terrorist groups find unacceptable, they also provide lucrative markets for criminals. In short, the target countries are the same; the difference is that criminals seek to exploit them and terrorists to hurt them.

Third, there are few if any islands of security or safe havens in this new world. The United States prior to September 11 still considered itself as such, but this notion was dispelled as the towers of the World Trade Center collapsed. Part of the reason for this transformation is that in an age of unprecedented cross-border flows - whether of people, money, commodities or digital signals - the capacity of even strong governments to monitor who and what enters and leaves the country is limited. Smuggling can succeed either by circumventing monitoring systems and control points or by going through them with false documentation. Borders have always had a permeability about them that Westphalian conceptions of the state found convenient to ignore. With globalisation, however, permeability has increased enormously: borders are simply not what they were. In the era of military and territorial competition among great powers, lines on maps meant a great deal; for terrorists, however, borders are minor barriers that are easily circumvented and little more than boundaries for target sets. And for criminals, borders demarcate market opportunities, as many illegal goods such as drugs increase in value as soon as they cross certain borders. Yet, at the same time as criminals and terrorist networks transcend and violate borders, they also use them for defensive purposes, finding weak or sympathetic states that provide some kind of safe haven.

The weakness of border controls is particularly pronounced when the state itself is weak. In Africa and Central Asia, for example, long borders are often not patrolled and there are many points of entry that simply cannot be monitored by states with limited resources. As a result, illegal immigration has become commonplace. Furthermore, criminals and smugglers traffic in a variety of products including art and antiquities, stolen cattle, fauna and flora, guns, drugs, diamonds and gold. Customs and immigration services 
are generally poorly developed, poorly trained, badly equipped and inadequately paid. As such, they are easily circumvented by relatively sophisticated methods of concealment or bought off by fairly modest exercises in bribery and corruption. They facilitate what Bayart, referring to large parts of Africa, has termed 'the economy of plunder, fraud and smuggling'. ${ }^{18}$

Fourth, the helpful distinction that was made shortly after the end of the Cold War between zones of peace and zones of turmoil has to be refined to incorporate the notion of spillover. ${ }^{19}$ In a globalised world, there is inevitable spillover from areas of turbulence and instability to zones of peace and tranquility. There are several vectors along which the connections are made. One of these is psychological: states in the zone of peace are held responsible for injustice or instability in the zone of turmoil. A second is immigration, which does not end old affiliations or moderate old enmities, but merely transfers them to new venues. Those in the diaspora retain links with the homeland and often send back financial remittances. The vast majority of these financial transfers take the form of legitimate economic assistance to families and are often eked out of relatively modest incomes. In some cases, however, financial proceeds generated through crimes such as drug trafficking and credit card fraud provide support for insurgency or ethnic conflict. ${ }^{20}$ Another vector operates through the dynamics of illicit markets. Although there are some flows such as stolen cars (and, in some cases, arms) from zones of tranquility to zones of turmoil, most illegal commodities flow from areas of turmoil into zones of peace and prosperity where there is significant demand for 'products' such as drugs, foreign women for prostitution, rare antiquities and the like. Closely linked to these flows is the diffusion of networked actors from the more troubled areas. The way in which drug traffickers and organised crime groups from the Balkans have spread into western Europe and taken control of heroin markets in several countries, for example, illustrates the kinds of dynamics that are generated by the demand for narcotics in zones of peace and stability.

Fifth, the transnational actors challenging security operate largely through networked organisational structures. As such, they are difficult to destroy with traditional military means. They prefer to hide and strike with surprise and devastating effect rather than engage in direct head-to-head combat. The United States in Afghanistan succeeded in part in creating a head-to-head military contest. Yet it also encountered the problem of an amorphous networked enemy, as al-Qaeda forces dispersed and fled into a variety of other countries. The United States, by toppling the Taliban, removed Afghanistan as a safe haven for al-Qaeda; yet there is a very real possibility that the members of the network have found other safe havens at least temporarily - in countries such as Somalia, Iran and Indonesia. One inadvertent - and disquieting - consequence of the United States success in Afghanistan is that al-Qaeda has been forced into becoming even a more diffused network actor. In the short term, this might inhibit its capacity to 
carry out further terrorist attacks; in the longer term, however, this might simply make it even harder to locate and combat.

There is also a danger of overestimating the impact of successful attacks on the core of the network: networks are not easily destroyed by decapitation strikes. Indeed, for decapitation to have a significant impact in degrading terrorist and criminal networks, it cannot be a single temporary measure. Decapitation has to be both successive and pre-emptive if it is to do more than temporarily destabilise the organisation. Yet another difficulty is that as networks become deeply embedded in societies and institutions, they are increasingly difficult to eradicate. Criminal networks, for example, are very successful in infiltrating legitimate industries and firms, and once embedded are difficult both to detect and to dislodge. Similarly, terrorist cells can operate in target countries, finding support and cover within ethnic and religious communities, and avoiding actions that arouse suspicions. Identifying them requires law enforcement strategies that are proactive rather than responsive, and that place an unprecedented premium on good intelligence. Unfortunately law enforcement agencies are not geared up to pursue such strategies. Instead, they are concerned with making cases that generate successful prosecutions and convictions and that serve to justify their budgets. The other difficulty is that both criminal and terrorist network connections are often transnational, whereas law enforcement remains stubbornly national. If this poses one kind of constraint, continued limits on the capacity of intelligence agencies to operate domestically create another. Even if cooperation between law enforcement and intelligence agencies is good, the result is still collection and analytical processes characterised by seams, gaps and disconnections. This absence of integrated processes is all the more debilitating because criminal activities, criminal transactions and the planning and implementation of terrorist strikes are seamless activities.

Even if law enforcement succeeds in disrupting networks, it will find them to be remarkably adaptable and resilient organisations with a capacity to regenerate themselves. Networks can learn and morph themselves: they can transform their shape, operations, modalities and size. They can contract and expand according to opportunities and constraints in their environment, and even when critical nodes are destroyed and critical connections severed, they are able to continue operating because of a high degree of redundancy. Although the United States and allied governments, since September 11 , have begun the process of adapting to the particular requirements of combating networked adversaries, the learning curve is likely to be both long and steep.

The sixth dimension of the new security paradigm is that some states are part of the problem rather than part of the solution: the world has entered the era of the qualified state. If part of the new security paradigm revolves around a competition between traditional bureaucratic and hierarchical states on the one side and agile, networked actors on the other, the problem 
is compounded by the fact that many states lack effective, efficient, bureaucratic structures characterised by integrity rather than susceptibility to corruption. Although the United States, after September 11, was very successful in mobilising not only its traditional allies but also other states in the effort to combat terrorism, two problems are inescapable.

The first is that some states ostensibly comply with the demands to join the war on terrorism, but tacitly defect from this effort. Saudi Arabia, for example, at one level has appeared to provide strong support for the United States in its efforts to attack the financial basis of al-Qaeda. Yet it is not clear that it has introduced vigorous measures to inhibit terrorist funding under the guise of charitable giving.

The second problem is that some states simply lack the capacity to combat transnational networks of criminals or terrorists. Many states along Europe's eastern and southern periphery suffer from lack of authority and legitimacy, low state capacity, and the existence of no-go zones that provide safe havens for a variety of illegal activities and those who engage in them. Endemic problems include capacity gaps and functional holes, which arise when the state fails to carry out responsibilities that are generally regarded as the norm for states. Many of these states are weak and have a very limited capacity to govern; they exhibit functional holes that are readily exploited by transnational criminals and terrorist networks. The most obvious manifestation of functional holes is the absence of effective social control and lawenforcement mechanisms, which allows organised crime and terrorist networks to operate in a low-risk environment. In effect, the networks exploit the space provided by the functional hole. Another such hole is the inability of many states to provide for the basic economic and social needs of their citizens. This failure can lead to migration from the legal economy to the illegal. It also provides opportunities for transnational actors to fill the hole. In many countries, for example, Islamic charities are increasingly providing the social safety nets that state authorities are unable to afford. In effect, a public function is fulfilled through private provision. Although such activities are obviously legitimate, they also provide opportunities for Islamic fundamentalists to spread militant forms of the religion that feed into terrorism. Terrorist networks that have embedded themselves in charitable organisations also use the opportunity to recruit new members. Moreover, as evidence from the trials relating to the United States embassy bombings in Kenya and Tanzania revealed, al-Qaeda has been particularly adept at using charities as cover for the movement of money and people. Another functional hole that has been particularly evident in Russia and other states of the former Soviet Union has concerned the regulation of business. Where the state has been unable to provide contract enforcement, arbitration of disputes or debt collection, organised crime has become a surrogate, in effect filling the functional hole and expanding its influence into the economy to a degree that is unprecedented. 
In some cases, of course, the capacity gaps and functional holes are so large that the state simply collapses. This outcome occurs particularly where there are ethnic rivalries, secessionist aspirations, religious animosities or tribal divisions. Indeed, one of the most significant features of the late twentieth and early twenty-first centuries is the resurgence of warlordism. Although there are important regional variations, warlordism of one kind or another has helped to fuel conflicts in Afghanistan, Tajikistan and the Balkans. It is a complex phenomenon that both combines and blurs categories that in other parts of the world are regarded as separate and distinct. Warlords, who typically engage in criminal activities and in insurgent, military or terrorist activities, achieve what can be termed a symbiosis between politics and accumulation. ${ }^{21}$ One manifestation of this is found in Africa, where the state is seen as the prize of politics, with the spoils to be distributed along tribal lines by the representative of the dominant tribe. This results in two phenomena: dictatorship where there is in effect a dominant warlord; and conflict among warlords where there is a struggle for dominance. Such conflicts revolve around control over resources, both in the legal economy and in the underground economy. Moreover, the resources that can be acquired through territorial control continue to fuel these conflicts, providing the wherewithal to continue fighting. Similarly, in Tajikistan's civil war from 1992 to 1997, conflict among rival warlords was intensified by the struggle for control over drug routes and markets, as heroin from Afghanistan was transshipped through Tajikistan. In Afghanistan itself, local warlords - prior to the consolidation of power by the Taliban and subsequent to the regime's overthrow - fought for control not only of drug cultivation areas, but also of trade routes, levying taxes on merchants passing through the territory under their control. One implication of all this is that political-military and sometimes terrorist activities on the one side and criminal activities on the other are combined as part of the warlord's day-to-day activities.

Nor are there easy solutions to these problems. In almost all cases of failed states, the lack of legitimacy and authority is reflected in the way in which many groups and individuals place their own narrow interests above the collective interest of the state and society. ${ }^{22}$ It is hardly surprising, therefore, that state building is an extremely difficult enterprise. Nowhere has this been more evident than in Bosnia. The Dayton accords envisaged the emergence of a centralised state which would increase its resource base and pave the way for the gradual integration of different ethnic communities. What has happened instead is that the separatist national parties have worked in close cooperation with organised crime. These parties, in turn, have obtained control over criminal markets, corruption and rent-seeking opportunities, and have used their position to enrich themselves at the expense of the overarching state apparatus. The state, in effect, has been 'ripped off' and organised crime has become a spoiler not only in a peacekeeping contingency, but 
also in the state-building endeavour. ${ }^{23}$ It seems likely that similar kinds of developments will bedevil Afghanistan as the United States tries to ensure that further neglect does not provide a continued safe haven, breeding ground and training camp for terrorists and drug traffickers.

The seventh feature of the new paradigm is the growing diffusion of technological capabilities. This is most obvious in the spread of weapons of mass destruction and the possible linkage between states that posses them and terrorist organisations that would be willing to use them against the United States and western Europe. Significant tensions between the Bush administration and western European governments over a possible attack on Iraq reflect divergent assessments of the salience and urgency of this issue. The Bush administration has regarded the terrorist use of weapons of mass destruction as a real threat that is inextricably linked to Saddam Hussein's programmes for developing or acquiring weapons of mass destruction (WMD). Whether or not Iraq is the supplier, the terrorist use of WMD is certainly not a contingency that can be excluded. As Bruce Hoffman pointed out several years ago, Aum Shinrikyo's use of sarin gas on the Japanese underground crossed a significant threshold. ${ }^{24}$ Moreover, for terrorist networks whose goal is to create mayhem and inflict large-scale casualties, WMD are ideal. In spite of the lack of evidence found in Afghanistan, it would not be surprising if al-Qaeda had acquired enough radioactive material to make a 'dirty bomb'. In the latter half of the 1990s, nuclear and radioactive material stolen from Russian installations and stockpiles was increasingly smuggled through Central Asia, the Caucasus and the Balkans, all areas in which al-Qaeda had a significant presence. The critical point about the use of such weapons by terrorist networks is that they are more likely than not to be delivered in unconventional ways and not by missiles.

James Rosenau's identification of 'sovereignty-free actors' underscores the growing importance of technology and expertise diffusion from traditional great powers to other states with respect to computers and information technology. ${ }^{25}$ Moreover, this is an area where entry costs for acquiring offensive capabilities are very modest. ${ }^{26}$ This is linked, of course, to the notion of asymmetric warfare, in which enemies are able to exploit aspects of modern societies and economies that have traditionally been seen as strengths but increasingly create concomitant vulnerabilities. Indeed, the corollary of the diffusion of information technology is that the enormous reliance of postindustrial countries on computerised information and communication systems for the effective functioning of their economies and societies is a major vulnerability. United States infrastructure, for example, presents a tempting target set to terrorist organisations. If terrorist networks, using a mixture of physical and cyber attacks, succeeded in destroying Fedwire and CHIPS, the two systems that provide wire transfers and funds settlements domestically and internationally, the damage to the United States financial system as well as to global financial markets would be enor- 
mous. Although backup installations, based on a well-established risk management ethos, provide a high degree of redundancy within the system, there is little or no redundancy of the system. Consequently, a well-coordinated systemic attack could prove profoundly debilitating. The September 11 attack on the Word Trade Center was not designed primarily as an attack on infrastructure, but certainly caused short-term problems for the financial services sector. An attack that specifically targeted the electronic payments systems could overwhelm the existing safeguards. Getting even has never been so feasible or easy.

The eighth characteristic of the twenty-first-century security paradigm relates to the paradoxical and perverse consequences of globalisation. Although globalisation has been widely hailed as facilitating the spread of liberal democratic values and free market economics, it has both a downside and a dark side that liberal neo-institutionalists were slow to acknowledge. Legitimate businesses have benefited enormously from opportunities to exploit global markets, but the major beneficiaries of globalisation have been transnational criminal networks. These networks use the global trade system to embed illegal products in legal commodity flows, the global financial system to move and hide their money, the global telecommunications system to transmit directives and messages, and the global transportation system to move people and products. Terrorists have exploited globalisation in similar ways, using the global financial system to move and hide their money, and the Internet to transmit messages through either steganography (messages hidden in digital images) or more simply the use of encrypted emails. In addition, both criminals and terrorists have used global diasporas and transnational ethnic networks as cover and recruitment for their activities. As a result, combating criminal and terrorist activity has become very difficult without impeding the rapid flows of money, goods and services on which modern commerce and finance depend; and without violating the civil liberties which are the hallmark of western democracies and facilitate the efficiency of the market. Although the equation between security on the one side and freedom of movement on the other has swung in the direction of security after September 11 , there is still a reluctance to interfere too much with a system of commerce based on just-in-time inventories and virtually unimpeded movements across borders. The adverse consequences of globalisation for national and international security must not be allowed to detract from the benefits of globalisation in economics and commerce. The subordination of security considerations, however, can have very serious consequences.

In addition to having a dark side, globalisation also creates discontents. ${ }^{27}$ Regarded by its adherents as an unmitigated benefit, globalisation has disruptive effects on traditional societies, contributes to the marginalisation of groups within societies and in some cases of whole societies, and brings with it a form of cultural imperialism that is regarded with enormous hostil- 
ity in certain regions and countries. There is also a gap between the speed with which ideas of the market economy have taken hold and the speed with which liberal democratic values and respect for human rights have become accepted as the norm. For many developing countries engulfed by globalisation, the result is growing prosperity for pro-western, non-democratic governments, and alienation of the large masses of the population who suffer from economic deprivation at the same time as their cultural norms are being eroded. In these circumstances, Benjamin Barber's notion of the clash between Jihad and McWorld proved to be prophetic. ${ }^{28}$ Al-Qaeda's attacks on the United States and the foiled attacks on western European targets were simply the opening salvos in a struggle that is partly a clash of civilisations and partly a struggle over the pervasiveness of globalisation. ${ }^{29}$ These attacks also reflected an anti-hegemonic impulse that, significantly, is manifested through transnational actors rather than emerging great powers. For those opposed to it, globalisation is not a neutral process so much as a project directed and dominated by the United States and its allies.

The ninth and final characteristic of the new security paradigm is the prevalence of disorder. Indeed, the management of great power rivalry has been superseded as a central theme of global politics by the issue of disorder versus governance. The security challenges of the twenty-first century are not the same as those of the twentieth: mass industrialised nations fighting one another to the finish have become passé. The obvious costs of such conflicts are compounded by the possibility that they will escalate to nuclear war either as a result of deliberate decision or through inadvertence and loss of control. Moreover, the source of most of these conflicts - struggle for geopolitical dominance in Europe - has been transcended by the evolution of the EU, a union that has tied together France and Germany, traditional enemies, in inextricable forms of political and economic interdependence. Western Europe - along with North America - has not only become the kind of 'security community' envisaged by Karl Deutsch but is extending this to selective states in central Europe. At the same time, the forces of disorder outside this security community, particularly emanating from Eurasia, have become increasingly formidable. Charles Tilly, in an oft-quoted comment, once noted that the state was simply the most efficient and effective form of organised crime. ${ }^{30}$ In effect, the state legitimised organised crime by transforming extortion into taxation, brute force into authority, and rule by fear into rule by consent of the governed. Yet, in the last decade or so organised crime has been fighting back with a new vigour and some success - in many cases penetrating state institutions and dominating important economic sectors. Similarly, the fact that the main challenge to United States hegemony comes from a transnational terrorist network rather than other states suggests that the world has entered the twilight of the Westphalian system. It is likely to be a long twilight, however, as powerful states continue to function effectively, to deploy vast economic and military resources, and to 
combat the forces of disorder that embody the new security challenges. Yet for states to have any chance of maintaining their pre-eminence in the international system and defeating new security threats from organised crime and terrorist networks, they have to fight smart as well as hard. Consequently, the final section of this chapter looks at the kinds of strategies the United States and western Europe need to adopt to meet not simply the immediate challenge posed by al-Qaeda, but also the long-term challenge presented by the forces of disorder.

\section{Conclusion: responding to the new security paradigm}

The difficulty for the United States and western European states in responding to the new security paradigm is that they have well-established diplomatic and military systems and institutions based almost exclusively on the traditional state-centric security paradigm. Governments are prepared and equipped to deal with threats from other governments. They are familiar with a struggle of like versus like in which the actor with most resources generally comes out ahead. They are far less comfortable with asymmetric warfare, where there are no rules and no front lines, strengths and vulnerabilities are sometimes indistinguishable from one another, and fighting smart can sometimes compensate for limited resources. Against this background, this section does not seek to elaborate detailed strategies for countering terrorism or organised crime. Instead, it establishes some precepts that could be helpful not only in guiding these strategies, but also in developing a long-term approach to managing the new disorder.

The first injunction is to think and act strategically. While this appears so obvious as to be superfluous, there are, in fact, several ways in which governments typically fail to meet this requirement. Thinking strategically requires a long view going beyond a concern with immediate failures and successes; some analysis of root causes of security problems; an assessment of the consequences of success as well as failure in existing responses; and systematic efforts to turn assessments into actions.

The second imperative is to know the enemy. This requires far better intelligence than ever before. Much of the necessary intelligence can be collected only through multilateral efforts - and United States and European intelligence agencies need to collaborate and share intelligence with each other even more fully than in the past. They also need to cooperate with foreign agencies that can infiltrate al-Qaeda and similar terrorist or criminal networks with greater ease and lower risk of detection than can intelligence personnel from NATO countries. Similarly, it is necessary to develop and maintain intelligence assets in zones of turbulence, so that vectors creating spillover to zones of peace can be anticipated. Knowing the new enemies also requires extremely effective techniques for fusion of highly classified and open source material, traditional intelligence and law-enforcement intelli- 
gence, foreign intelligence and domestic intelligence, and strategic warning and tactical indicators. To have any chance of meeting the new security challenges with any degree of real effectiveness, intelligence superiority is essential. Indeed, it is far more important than weapons superiority. The United States obviously enjoys military superiority over any challenger, whether state or transnational network, but in many contingencies such superiority is meaningless.

The third imperative is to think out of the box and avoid the temptation of locating new challenges in old conceptual frameworks. It is essential to adopt new ways of thinking, beyond the conventional wisdom, and to deviate considerably from traditional ways of doing things. Old conceptualisations, categorisations and distinctions are no longer adequate and, in some cases, no longer relevant. The familiar distinction between domestic and foreign, for example, is of little utility when considering transnational threats that typically cross multiple borders. The way in which the threat from weapons of mass destruction is assessed is similar: it is conceivable, for example, that the delivery system of choice for a nuclear strike against United States citizens will be an intermodal container that is brought into a busy United States port as part of a legitimate shipment of goods. In the new security environment, container defence might be more important than ballistic missile defence - especially in relation to homeland security. While the Bush administration is fully committed to defence against ballistic missile attack, therefore, some of the effort and resources devoted to this could usefully be diverted to detection and prevention of other, less orthodox delivery systems. Another area where far more needs to be done is in identifying the requirements of network warfare and how it can be fought most effectively. Analyses by John Arquilla and David Ronfeldt have provided an excellent basis for this. ${ }^{31}$ Indeed, in the aftermath of September 11 , the US secretary of defence, Donald Rumsfeld, adopted the rhetoric of network warfare. Yet, in Afghanistan it is not clear the United States military undertook serious network damage assessment, or began to anticipate the ways in which the al-Qaeda network could adapt to the new security environment it now faces. For the most part, the United States relied on conventional military tactics supplemented by special forces. For United States military planners, therefore, the challenge is to think in very different ways about warfare. The United States is no longer involved in conflicts in which industrial or technological superiority is the simple key to victory. On the contrary, it has to confront enemies for whom traditional notions of victory and defeat mean very little so long as they can continue to inflict pain on the United States and its citizens.

Finally, the United States needs to reassess the institutions and procedures through which national security policy is made and implemented. Along with its NATO allies, the United States faces what is, in effect, a crisis of institutions: many of those institutions that still govern societies were 
organised primarily for the industrial age, not the digital age. They are essentially hierarchical, slow, bureaucratic organisations in which the chain of authority runs top-down, in which creativity is stifled, and in which standard operating procedures rule out innovative responses and solutions. Remedying the deficiencies will not happen overnight. As a matter of urgency, however, it is essential to break down the institutional stove-piping that characterises not only intelligence collection and analysis but also strategic and policy planning and task implementation. Institutional innovation needs to be encouraged at all levels, so that traditional bureaucratic distinctions and demarcations can be overcome. A premium must be placed on the creation of smart institutions to combat smart enemies. Anything less is unlikely to succeed.

In other words, as the United States and its NATO allies face a new strategic environment, particularly along Europe's eastern periphery, they need to develop new methods and procedures for responding to it. The enemies are flexible, nimble and innovative; governments are laboriously slow, wedded to established methods, and restricted by standard operational procedures. Unless the NATO member-states are able to transcend these limitations and respond to disorder in systematic and innovative ways, the forces of disorder will emerge triumphant and the Westphalian system will be doomed.

\section{Notes}

1 See Walter Laqueur, The New Terrorism (New York: Oxford University Press, 1999); Bruce Hoffman, Inside Terrorism (London: Indigo, 1999); and Ian Lesser et al., Countering the New Terrorism (Santa Monica: Rand Corporation, 1999).

2 For a very succinct and useful analysis of these changing characteristics see Bruce Hoffman, 'Terrorism Trends and Prospects', in Lesser et al., Countering the New Terrorism, pp. 8-38.

3 Brian Jenkins's comment 'terrorism is theater' is quoted in Hoffman, Inside Terrorism, p. 38.

4 See Anthony Lake, Six Nightmares (Boston: Little, Brown, 2000), esp. pp. 56-7 where he discusses the role of Richard Clarke in sounding the warnings and developing responses.

5 Martin Bright, Antony Barnett, Burhan Wazir, Tony Thompson and Peter Beaumont in London; Stuart Jeffries in Paris; Ed Vulliamy in Washington; Kate Connolly in Berlin; Giles Tremlett in Madrid; Rory Carroll in Rome, 'The Secret War: Part 1', Observer, 30 September 2001.

6 David Bamber, Chris Hastings and Rajeev Syal, 'Bin Laden British Cell Planned Gas Attack on European Parliament', Daily Telegraph, 16 September 2001.

7 Peter Finn and Sarah Delaney, 'Al Qaeda's Tracks Deepen in Europe: Surveillance Reveals More Plots, Links', Washington Post, 22 October 2001.

8 Ibid.

9 Bruce Johnston, 'Nerve Centre for Bin Laden Terrorists is Smashed in Italy', Daily Telegraph, 6 April 2001. 
10 Wolfgang Krach and Georg Mascolo, 'Highly Alarmed', Der Spiegel, 9 April 2001, pp. $22-4$.

11 Finn and Delaney, 'Al Qaeda's Tracks'.

12 Judith Miller and Sarah Lyall, 'Hunting Bin Laden’s Allies, U.S. Extends Net to Europe', New York Times, 21 February 2001.

13 Ibid.

14 Johnston, 'Nerve Centre'.

15 Bright et al., 'The Secret War: Part 1'.

16 Peter Finn and Pamela Rolfe, 'Spain Holds 8 Linked to Sept. 11 Plot: Direct Role, Ties to Cell in Germany are Alleged', Washington Post, 19 November 2001.

17 A tenth characteristic of the new security paradigm, although not yet relevant in this particular geopolitical context, is the rise of mega-cities, that is, cities with a population of over 10 million people. Mega-cities are often highly dysfunctional and incubators for all sorts of violence - both criminal and terrorist. They bring together the extremes of wealth and poverty and are increasingly characterised by growing levels of violence, facilitated, in part, by the global trade in light arms. It is not surprising, therefore, that these urban concentrations are also characterised by no-go zones where state authorities are conspicuously absent. These mega-cities, like Shanghai and San Paulo, are breeding grounds for disease, political violence and organised crime, as those who are downtrodden, deprived and alienated increasingly seek to get rich (through crime) or get even (through terrorism).

18 Jean-François Bayart, Stephen Ellis and Béatrice Hibon, The Criminalization of the State in Africa (Bloomington: Indiana University Press, 1999), p. 23.

19 Max Singer and Aaron Wildavsky, The Real World Order: Zones of Peace, Zones of Turmoil (Chatham, NJ: Chatham House, 1996).

20 Tamil communities in western Europe and Canada, for example, often include strong supporters of the Liberation Tigers of Tamil Elam (LTTE), who use crimes such as extortion, drug trafficking and various forms of fraud to generate proceeds to support the LTTE. See Peter Chalk, 'Liberation Tigers Of Tamil Eelam's (LTTE) International Organization and Operations: A Preliminary Analysis', Commentary No. 77, Canadian Security Intelligence Service (Winter 1999). This document can be viewed at www.csis-scrs.gc.ca/eng/comment/ com77_e.html.

21 Bayart et al., Criminalization of the State, p. 8.

22 William Reno, Warlord Politics and African States (Boulder, CO: Lynne Rienner, 1998), pp. 2-3.

23 For the notion of a 'spoiler', the author is grateful to Stephen Stedman, 'Reflections on Implementing Peace Agreements in Civil Wars', www.glencreecfr.ie/StedmanPaper.htm.

24 Hoffman, Inside Terrorism, p. 202.

25 On sovereignty-free actors see James N. Rosenau, Turbulence in World Politics (Princeton, NJ: Princeton University Press, 1990).

26 This is one of the themes in Roger Molander et al., Strategic Information Warfare (Santa Monica: Rand Corporation, 1996).

27 See James H. Mittelman, The Globalization Syndrome: Transformation and Resistance (Princeton, NJ: Princeton University Press, 2000), p. 234.

28 Benjamin R. Barber, Jihad Versus McWorld (New York: Ballantine, 1996). 
29 For the clash-of-civilisation thesis, see Samuel P. Huntington, The Clash of Civilizations and the Remaking of World Order (New York: Simon and Schuster, 1996).

30 Charles Tilly, 'War Making and State Making as Organized Crime', in Peter B. Evans, Dietrich Rueschemeyer and Theda Skocpol (eds), Bringing the State Back In (Cambridge: Cambridge University Press, 1985), pp. 169-91.

31 John Arquilla and David Ronfeldt, Networks and Netwars (Santa Monica: Rand Corporation, 2001). 